\title{
Study guides and Australian documentary: The role of bridging materials in building educative, cultural and economic value
}

\section{Ruari Elkington (iD}

\section{How to cite this article}

Elkington, R. (2020) 'Study guides and Australian documentary: The role of bridging materials in building educative, cultural and economic value'. Film Education Journal, 3 (2), 206-17. Online. https://doi.org/10.14324/FEJ.03.2.07

Submission date: 12 August 2019

Acceptance date: 12 May 2020

Publication date: 26 November 2020

\section{Peer review}

This article has been peer-reviewed through the journal's standard double-blind peer review, where both the reviewers and authors are anonymized during review.

\section{Copyright}

(C) 2020 Elkington. This is an open-access article distributed under the terms of the Creative Commons Attribution Licence (CC BY) 4.0 https://creativecommons.org/licenses/by/4.0/, which permits unrestricted use, distribution and reproduction in any medium, provided the original author and source are credited.

\section{Open access}

The Film Education Journal is a peer-reviewed open-access journal. 


\title{
Study guides and Australian documentary: The role of bridging materials in building educative, cultural and economic value
}

\author{
Ruari Elkington* - Queensland University of Technology, Australia
}

\begin{abstract}
The use of documentary, and in turn the value of documentary, is well established in formal education contexts. In addition to an established pedagogical value, this article examines the cultural and economic value of documentary in education through both national legislative reviews (the Australian Law Reform Commission's (ALRC's) Copyright and the Digital Economy) and a specific learning resource in the form of study guides. Within this research, study guides function as a means to explore the plurality of ways in which documentary may be valued through several stakeholders invested in sustaining educational engagement with the form. Most notably among these stakeholders is copyright collection agency Screenrights, which bridges the valuing of documentary between screen and education sectors alongside national funding agency Screen Australia and the Australian Teachers of Media (ATOM), an independent, non-profit, professional association promoting the study of media in education. ATOM in particular is synonymous with the creation of study guides for documentary films. Investigating the educative, cultural and economic value of study guides offers a discrete albeit valuable study of the ways in which documentary functions within Australian education contexts.
\end{abstract}

Keywords: Screenrights, study guides, Australian Teachers of Media (ATOM), documentary

\section{The Australian Law Reform Commission (ALRC) - Copyright and the Digital Economy}

Since 1990, Screenrights has been a vital element in granting Australian educators significant flexibility in using TV, film and documentary content as a result of educational exceptions within existing copyright provisions. However, in 2013, this flexibility came under significant scrutiny as educational use of screen content became a key consideration of the Australian Law Reform Commission's (ALRC) review, Copyright and the Digital Economy (ALRC, 2014). Most relevant to both education and screen production sectors were the ALRC's recommendations around the continuation of 'statutory licences' for audiovisual content. These licences form the copyright mechanisms, allowing educators to copy and share television broadcast content as well as text and image resources. Administered through copyright collection agencies such as Screenrights, the Copyright Agency Limited (CAL) and Viscopy, all copying and reuse of content in education occurs under the 'fair dealing' provisions of the 1968 Australian Copyright Act. The 2013 review gave voice to many of the debates examined in this article, debates that still animate the screen and education sectors and highlight the plurality of value attached to the use of screen content, such as documentary, in education contexts. 
Anticipating the final 2014 report, the ALRC released a discussion paper in 2013 (ALRC, 2013), which recommended replacing the existing 'fair dealing' exceptions in the Copyright Act with an open-ended 'fair use' exception more closely mirroring the US fair use model. The 2013 discussion paper acted as a lightning rod for the screen content industries and revealed a range of industry agendas and positions - both broadly, in relation to digital challenges around copyright, and specifically, in terms of the education market for screen content and the perceived negative impact a US-style model of fair use could bring. Several submissions focused on the perceived negative aspects of replacing the statutory licensing schemes with a voluntary licensing regime. Largely, this opposition came from within the Australian production, distribution and copyright collection areas (Copyright Agency/Viscopy, Screenrights, Screen Producers Association of Australia). Summing up the general tenor of many submissions opposing any amendments, Executive Director of the Australian Copyright Council, Fiona Phillips, argued that 'fair use won't mean a fair return for creators' (Phillips, cited in Tiley, 2013) and that the ALRC recommendations 'are likely to reduce the opportunities for creators to license and receive a fair return for their work' (ibid.). Other screen sector submissions to the review went further. Moving in the entirely opposite direction of these liberalization efforts, Screenrights not only opposed the 'fair use' copyright amendments, citing potential negative impact to rights-holders' remuneration, but also sought to build further remuneration for rights-holders from the educational use of their work. Seeking to extend its purview, Screenrights also sought an extension of the Screenrights licence to render currently excluded content, such as the $A B C$ iview online catch-up transmission, remunerable.

The ALRC review received 223 wide-ranging institutional submissions covering an array of educational interests spanning libraries, private and public schools, technical and further education institutions (TAFEs), state departments of education, educational peak bodies, universities and larger educational representatives such as the Copyright Advisory Group for Schools (CAG). Other submissions were received from assorted industry and education parties with varying degrees of commercial and non-commercial interests. This cross-section of education-affiliated participants offers valuable insights into the diversity of the education sector and the many viewpoints affecting commercial usage of licensed copyrighted material.

The ALRC review also highlighted the understandable sensitivity of some in the education sector around their inclusion in what has been termed the 'education market'. Some of the institutional submissions mentioned, including the CAG, were uncomfortable with the private sector viewing education as a market to 'exploit' like any other. Conceptualizing the 'education market' in research remains sensitive terrain as Daniel Menchik (2004: 197) noted: 'the line that separates benevolent, authentic concern for student learning enrichment from self-interested entrepreneurship is difficult to ascertain'. Here the complex relationship between education as an agreed societal good, combining public policy and social responsibility, alongside the budgets required to fulfil those responsibilities, is underlined. After 18 months, 109 consultations, 870 submissions and the resultant 30 recommendations for reform, the ALRC's (2014) 'key recommendation [was] for introduction of a fair use exception to Australian copyright law'. The ALRC recommendations suggested current exceptions to the Copyright Act were not effective enough, and the Statutory Licences were recommended to undergo considerable reform. In 2020, the specific legislative impacts of this report await the future and as yet unknown policy implications of two recent and related reviews, which include screen content in their remit: an Australian Senate enquiry into the Economic and Cultural Value of Australian Content on Broadcast, Radio and Streaming Services and the Australian and Children's Screen Content Review. 
The ALRC review also provided a valuable opportunity for educators to offer a view on what was characterized as the onerous reporting and significant costs of Screenrights membership. In its ALRC submission, the collective CAG cited an internal survey conducted among 379 government, Catholic and independent schools across primary, secondary and combined grade levels. A CAG internal survey informed the submission that 'the Australian education sector currently spends upwards of [AU] \$665 million per annum on purchasing educational resources for Australian schools, an amount over and above the [AU]\$80 million on copyright licensing fees currently paid to collecting societies' (CAG, 2013: n.p.). While this figure encompassed a broad range of resource provision, of which screen content purchasing and licensing is but one, it represents a significant spend from schools, and the screen sector in Australia is an undeniable beneficiary. Similarly, the Universities Australia (UA) submission to the ALRC review (UA, 2012), representing interests of the tertiary sector, also indicated a significant annual spend on digital resources (AU\$256.7 million).

Tertiary sector dissatisfaction with monies paid to collecting societies is not a new phenomenon. However, historically, this dissatisfaction has largely focused on the print/ image/text material collected through CAL rather than Screenrights screen content. In 2000, Michael Lean, then copyright officer for Queensland University of Technology (QUT) and Griffith University, identified in an interview that 'The relationship with the collecting societies has not been an easy one, and while the universities have always agreed that equitable remuneration for information access should be paid, the issue of what is fair and equitable has been a stumbling block' (Lean, 2000: n.p.). The UA submission to the ALRC (UA, 2012) disputes the ongoing relevancy of the statutory licences, although, in conjunction with direct licences, these copyright mechanisms continue to be a key means by which screen content like documentary is accessed by Australian educators.

\section{The remunerative value of documentary - Study guides and Screenrights}

Having established the recent historical context through which education and screen sector interests have been promulgated, this section examines the plurality of value through which screen content such as documentary may be better understood, beginning with economic value. Screenrights conduits economic value for the documentary sector through its work as a copyright collection agency. However, through Screenrights, this economic value is tightly bound to the pedagogical value Screenrights provides educators via its online resource centres, programme guides, newsletters and the wider distribution of Australian Teachers of Media (ATOM) study guides. However, while the pedagogical value of documentary within education contexts is well established (Gorski, 2003; Hess, 2007; Stoddard, 2009), the important role Screenrights plays in creating and returning benefits for both the education and screen sectors remains under-researched.

For over 30 years, Screenrights has occupied a distinct role in connecting the disparate worlds of formal education and (often highly) informal screen content production. The following quote from Melbourne documentarian John Lewis features in a sidebar of rights-holders' testimonials on the Screenrights website and highlights a confounding aspect of this connection. Lewis's quote references Screenrights' financial returns as both welcome and unpredictable in equal measure for Australian producers:

Producer to office: 'Listen up. We can pay the rent or go to the pub.'

Intern at computer: 'What's Screenrights? They just sent some money.' 


\section{Producer: 'How much?' \\ Intern: '\$5341.32.' \\ Producer: 'Listen up. We can pay the rent AND go to the pub! Put your shoes on.'}

Beneath the irreverent tone of Lewis's comment sits a serious and businessunderpinning point: the money Screenrights returns from the educational use of documentary is a vital, albeit unpredictable, source of support to the Australian documentary sector. Indeed, the funds returned to Australian documentary makers from educational use of their content have historically been a lynchpin of the sector's survival and continued supply of high-quality work for education audiences. As Zubrycki (2019) outlines in 'The changing landscape of Australian documentary' Platform Paper, 'Screenrights was set up specifically to administer the funds collected when educational institutions copied programs broadcast on television. These were usually the largest source of returns for a local film and were crucial to keeping our companies afloat and growing our business.'

Despite a genre agnosticism mandated by legislative restrictions around broadcast content (Screenrights can only record and distribute what is broadcast by free-to-air and pay television), Screenrights' reporting consistently shows documentary to be the most widely used screen genre in Australian education. Consequently, Screenrights both drives documentary demand within education through access to services such as programme guides, resource centres and linking to ATOM study guides, and also responds to, and is informed by, the widely acknowledged and longstanding deployment of documentary in education. In the 'What we do' section of the website, Screenrights clearly positions the 'value-add' of its work in seeking to align with the pedagogical aims of education while aiming to combat any negative perception of the organization as a solely revenue-focused collection agency:

Screenrights brings filmmakers and educators together through online resource centres. Teachers can find television content relevant to their learning area, order copies of programs and use free resources, such as study guides and articles. Screenrights has its own online educational video platform, EnhanceTV, and also licenses other resource centres for this purpose, including ClickView, TV4Education, eTV (NZ) and Informit. (Screenrights, 2020)

Within the Australian documentary sector, Screenrights' functions in both encouraging and remunerating educational use of screen content are largely welcome (as evidenced by Lewis's ebullient comment) but, equally, not well understood. Understanding how copyright collection agencies, such as Screenrights, work, and how they function to disseminate educational resources around nationally important screen content, particularly in the area of documentary, remains an under-researched approach, albeit one that might help us flesh out the various networks and actors that contribute to the cultivation of a vivid screen culture in formal educational settings.

The development and deployment of study guides are important as these guides function as a discrete yet powerful way by which to understand the network of connections reinforcing the plurality of documentary's value in education contexts - of both pedagogical value to educators and of economic value to the screen sector. At their most basic, study guides are text- and image-based PDFs that contextualize a documentary within clear curriculum strands, and link a film's content and themes to promote discussion and aid in lesson planning. Study guides and other bridging materials, 
such as websites, audio guides and other online and physical materials, assist educators in identifying and 'curating' their own lesson plans around documentary. Study guides, including interactive digital versions, have emerged as key materials to scaffold the value of screen content and in turn deliver an improved understanding of film and film literacy within education. Janson (2019) has parsed the discourses and practices of Swedish film education through a study guide lens, in particular the role of such guides in fostering particular sociocultural perspectives. As in the Swedish context, Australian study guides exist as a 'somewhat vague and varying genre, oscillating between educational materials and cultural journalism, containing suggestions for lectures and hard facts, as well as film analysis' (Janson, 2019: 95). While a deep textual analysis of Australian study guides sits outside the scope of this article, Janson's work significantly advances the literature on study guides and provides clear attributes and meta-discursive ingredients for scholars to use in further interrogation of these learning materials.

Further supporting the contention that study guides function as educative and economic drivers of documentary value in education, Screenrights (2009) argued 'there is strong anecdotal evidence to support the notion that the production of these guides increases the likelihood that a title will be copied and used in an educational environment thus increasing the returns to rights-holders'. By 2012, Screenrights had engaged its members in research to support the anecdotal evidence it cites: 'Producers regularly tell us that study guides are an invaluable marketing tool and that strong educational resources improve the likelihood of their programme being copied and used in the educational sector.'

Screenrights is not an educational institution, nor is it a commercial forprofit business, yet the quote from its website and Figure 1 highlight the practical and philosophical divide between both stakeholders (education and screen) that Screenrights seeks to bridge. The quote is sourced from Screenrights members who make a living not as educators but as film and documentary producers. That they would harness the language of business and refer to a study guide as an 'invaluable marketing tool' should neither surprise nor negate the value of that 'tool' when deployed by educators in a learning environment. To understand the function of Screenrights is to hold both these value, educative and economic, front of mind and acknowledge that while they remain distinct, they can, and do, coexist through mediabridging materials such as study guides. In turn, any consideration of study guides

\begin{tabular}{|c|c|c|}
\hline \multirow{3}{*}{$\begin{array}{l}\text { 3. If a program had a study guide accompanying it, would this influence your } \\
\text { decision to use the program in the classroom? }\end{array}$} & \multicolumn{2}{|c|}{$\checkmark$ Create Chart $\downarrow$ Download } \\
\hline & Response & Response \\
\hline & Per cent & Count \\
\hline 口 & $72.3 \%$ & 478 \\
\hline$\square$ & $9.5 \%$ & 63 \\
\hline$\square$ & $18.2 \%$ & 120 \\
\hline & answered question & 661 \\
\hline & skipped question & 57 \\
\hline
\end{tabular}

Figure 1: Study guides

Source: Adapted from Screenrights (2012) 
would be remiss without an acknowledgement of the crucial role ATOM plays in their conception, creation and distribution.

ATOM is an independent not-for-profit professional association promoting the study of screen and media literacy. ATOM's Peter Tapp has previously acknowledged the bridging role of study guides in delivering value to both the education and screen sectors:

What we have, which is unique, is Screenrights and the system we have for the production of study guides and how, through Screenrights, money is channeled back to filmmakers. Also how the study guides give teachers the education material they would not be able to produce, in the time available, themselves. (Tapp, 2014: n.p.)

Outside these far-ranging debates around the provisions and exceptions of copyright, fair dealing and fair use, Screenrights (and the 1968 Copyright Act that underpins it) remains a robust component of the Australian education landscape and an organization that Australian educators must both continue to work with and demand value for money from.

\section{The cultural value of documentary - Study guides and Screen Australia}

The well-established cultural value of documentary in Australia is evidenced in part by the visibility of the form through festivals and state and federal screen agency support. This is in addition to significant documentary commissioning, funding and acquisition by major public broadcasters Australian Broadcasting Corporation (ABC) and Special Broadcasting Service (SBS). Australian documentary institutions include the Australian Documentary Forum (OzDox), the Australian International Documentary Conference (AIDC), the Antenna Documentary Film Festival and the Documentary Australia Foundation (DAF). Many of these organizations have strong and well-established links to education. These links are in keeping with long-standing implicit and explicit state support for documentary predicated on Griersonian notions of documentary films delivering a demonstrable societal good through educational use.

As cogently argued in the Australian Film Commission discussion paper 'Documentary production and funding in Australia' (AFC, 2004), 'Australian documentary practice fulfils a cultural role in that it reveals Australians to themselves in a way that no-one else can or will do.' The paper goes on to link state subsidy of documentary and the cultural role of the form by suggesting, 'Some players argue that cultural production should be the overriding role of the documentary sector in Australia and that all government subsidy should be utilised to this end.' Indeed, globally, documentary makers have historically had to rely on government subsidies and institutional support to produce their work (Burns and Eltham, 2010; Fraser, 2012). Nick Fraser (2012: 29) notes that state support in Britain, and in turn educational expectation, has existed since the 1940s, and that the documentary sector would not exist without it: 'There was no commercial market for factual film and the financing of documentary film required public bodies.' Similarly, Australian documentary exists currently and historically as both subsidized art form and valued cultural product.

The AFC's 2004 discussion paper identified this financial support as a historical constant, stating, 'Documentary practice in Australia is a substantially government subsidised endeavour', with more recent scholars such as Zubrycki (2019) both highlighting this historical support while lamenting its decline. Established in 1975 by 
the Whitlam Government, following the creation of the Australia Council in 1973, the AFC marked the beginning of 'a national policy of sizeable direct public subsidies for Australian production, although limited subsidies for documentary production had existed since 1945' (Burns and Eltham, 2010: 3). This historical and current subsidy of the form exists alongside an expectation that, having been granted financial support, many documentaries would be of direct benefit to education. The long-standing educative role of documentary has led to a tacit expectation on behalf of funding bodies that documentary, arguably more so than feature films, needs to deliver on multiple levels to both entertain and inform the public.

In addition to documentary value being articulated at a national cultural policy level, the form has historically been a vital part of the educative and 'nationbuilding' efforts of Australia. This is evidenced as early as The Inauguration of the Commonwealth (1901), identified by the National Film and Sound Archive (NFSA) as a strong contender for the title of Australia's first feature documentary. The Inauguration of the Commonwealth also marks the beginning of state support of documentary production through the New South Wales (NSW) Government commissioning the Limelight Department, then the film production arm of the Salvation Army, to make the film. Of note is that Australia's first documentary film was not a self-started commercial undertaking - state support underpinned documentary endeavours in 1901 and continues to the present day.

In the discussion paper 'Documentary funding: Stories that matter', released by Screen Australia for the 2014 AIDC, the cultural value of the NFSA and that of these documentaries to education were highlighted. The paper stated, 'One of the ways cultural value is recognised is through the deposit of projects with the National Film and Sound Archive (NFSA) as part of the national collection of audiovisual material.' It went on to echo film scholars (Shelton, 2004; Aufderheide, 2007), in arguing a 'culturally relevant documentary slate also indirectly serves the needs of the educational sector and enables students to explore issues from different angles' (Screen Australia, 2014). On this front the NFSA is succeeding. The NFSA Annual Report 2012-13 (NFSA, 2013) stated the organization's targets had been exceeded over that period, with 44,258 students engaging with education programmes.

In linking this historical and current cultural value of the form with the work of an organization such as Screenrights, FitzSimons et al. (2011: 242) have argued the popularity of documentary content via the copyright collection agency may augur a wider cultural debate on the preservation of the form's intrinsic and educationally desired qualities:

The fact that Screenrights figures show documentaries continue to make up a substantial proportion of the programs copied and communicated to the more than four million students in Australian classrooms underlines the need for a policy framing documentary practice that safeguards its truth telling function and prevents documentary's complete integration into broadcast factual entertainment and public relations.

As FitzSimons et al. suggest, historically, documentary has been parsed in education settings with a set of cultural value expectations quite distinct from feature films. This is where compelling documentary storytelling, distinct from instructional, expository or purely didactic factual content, has always excelled. As Gresham Bradley (2014) argues, 'Documentaries are very rarely the source of specific instructional information but they will provide meaning, context and answer the reasons "why should I be interested in this at all?" They tend to show how whatever topic is being taught fits into and works in the real world.' 
In the Australian context, a further convincing indicator of documentary's cultural value in education can be seen in the funding conditions of federal agency Screen Australia. FitzSimons et al. (2011: 132) note that 'from 2002, the Corporation required producers of films it supported to be signed-up Screenrights members in order to receive revenue for the broadcasting of their work ... and to build [AU] $\$ 2000$ into their budget for the production of a study guide to accompany their film'. Notably, and in indication of the cultural value of the form, the allocation of a study guide budget line item is not a requirement of Screen Australia-funded feature films. This Screen Australia policy clearly signals two things in relation to how the cultural value of documentary is considered at an institutional level: first, a clear acknowledgement of the privileged function and pedagogical value of documentary in education; and second, a clear understanding of the value of bridging materials such as study guides in contextualizing and encouraging the use of documentary in the education sector.

Unsurprisingly, when considering their own research articulating the link between study guide availability and educational use, Screenrights argued for Screen Australia's dedicated study guide funding to continue in the major Screen Australia 'Stage 2' review in 2009. In light of the success of its subsidiary and resource centre, EnhanceTV, Screenrights (2009) suggested that study guides 'form an integral part of the service that is offered to education to support both the use of film and television in the classroom and the teaching of media literacy. Screenrights would strongly urge that funding support for these guides continue in the future.'

As evidenced by this Screen Australia funding, one historically strong (and still developing) site of connection among education, the documentary sector and copyright agencies such as Screenrights is the development of study guides. These bridging materials, between screen production and education setting, have performed to help subsidize continuing documentary production, through educational licences, but also reiterate the cultural value of documentary as a nationally important mode of screen representation.

\section{The pedagogical value of documentary - Study guides and the ATOM}

ATOM is an independent, non-profit, professional association promoting the study of media in education. As a professional association bridging the screen and education sectors, ATOM is a significant and long-standing stakeholder in the distribution, promotion and curriculum positioning of documentary film for Australian educators. ATOM's relevance is underlined not only through the professional association work it facilitates in networking Australian teachers of media (a curriculum strand representing significant documentary use), but also through ATOM's multiple publishing and outreach efforts.

First, ATOM (2014) argues that its reach into the Australian screen sector extends beyond simply teachers of media and into 'media industry personnel, a range of media, education and government organisations and, increasingly, the general public interested in the media'. This broad audience base goes some way towards explaining the organization's varied publishing, promotion, outreach and distribution efforts around multiple forms of media (including documentary). In addition to the creation of traditional, and now interactive, study guides, ATOM distributes screen media through its Education Shop, publishes two film journals (Metro and Screen Education), runs professional development activities, organizes film screenings for teachers, holds national conferences ('Screen Futures', last held in 2016) and annually recognizes 
excellence in over 30 categories of film, television, animation and multimedia through the ATOM Awards.

ATOM also offers an email alert service that acts as a reminder for newly released film and documentary content. Email alerts range from educator-exclusive cinema screenings through to reminders for schools to record a broadcast documentary. From the documentary sector's perspective, the ability to reach media teachers through email both on a state-by-state and national basis is valuable. The potential benefits for the documentary sector of generating early educational interest in a film range from school bookings during a theatrical release through to triggering increased income for Screenrights via educational reminders of a programme's scheduled TV broadcast. Viewed as a whole, the outreach efforts of these ATOM initiatives demonstrate an organization operating a range of innovative services in partnership with its stakeholders in the education and screen sectors.

In addition to the broad suite of activities mentioned, ATOM functions as the single largest producer of study guides in Australia. Study guide creation involves initial contact being made with ATOM by a documentary maker or distributor wishing to promote their work within education. ATOM will assess the programme against the current curriculum and, depending on suitability, employ a team of teachers within the identified subject area to produce the guide. ATOM regularly produces guides for feature films, documentaries, television shows and exhibitions, with all guides available initially as free PDFs via the Metro magazine website before transferring to the ATOM Education Shop where they are made available for AU\$4.95 each. ATOM also has a history in creating study guides around individual films as apps for iOS and Android tablets. In partnership with Victorian cross-platform developers NMG, ATOM has developed two interactive study guides: Oranges and Sunshine and Kapyong, as well as additional interactive guides for the feature film Blame and the documentaries Wide Open Road and The Triangle Wars. As ATOM's Peter Tapp attested in 2014, in relation to documentary specifically:

The demand from schools has grown every year for the past six years or more. The reason for saying this is ATOM is asked to produce more study guides with each passing year. Also, it appears that the pool of funds that Screenrights distributes to filmmakers increases each year. Also, the number of downloads of PDF study guides and Metro and Screen Education articles increases each year. (Tapp, 2014: n.p.)

By acknowledging the pedagogical value of study guides, and in turn the remunerative and cultural value they unlock in documentary, the likelihood of deeper engagement and more sustained use of the work increases for screen and education sectors. ATOM continues to do important work in this area as a result of deep institutional expertise, bolstered through the existing funding for study guides via Screen Australia. Within the New Zealand context, a document provided by eTV titled 'eDMC pilot: Extending New Zealand documentaries with enhanced digital media content' clearly articulates how study guides can help build the plurality of value identified in this research. Quoting the head of EnhanceTV, Mike Lynch, the pilot paper suggests:

The use of a study guide in class necessitates the screening of the film at school and therefore offering greater exposure of the programming to wider audiences. Each month, collectively more than 40,000 individual PDF study guides are downloaded from the Metro magazine and EnhanceTV websites. Once a study guide is downloaded, many copies are printed and 
handed out. This pass-around effect extends awareness of the content in wider and wider numbers of target audience members. For example, figures show that one study guide download can be used by more than 60 students. (eTV, 2014: 6)

An awareness of the curriculum and subject-specific relevance of documentary films, exemplified through the creation of bridging materials such as study guides, is a key driver for educational use and, in turn, the value of documentary film. The crucial alignment of the right documentary, supported by the right bridging materials, will continue to build the plurality of ways in which the education and screen sectors value the form.

\section{Conclusion}

As this article has argued, the work of Screenrights in facilitating educational use of screen content, and thus valuing that content, is broadly acknowledged within Australian education. In turn, Screenrights continues to deliver value for the screen sector in two related yet distinct ways - collecting funds and administering those funds. Without effective work on both these fronts, it might be argued that the production sector's engagement with educational settings in promoting the cultural worth of the documentary form is at risk. While collecting funds from educational institutions' use of copyright works and returning those funds to rights-holders may appear to be a single function, they remain two challenging sides of the same coin. Surveying educational use of screen content to arrive at a representational sample of programmes, and in turn a representation of corresponding rights-holders, is a complex task, albeit one that has simplified since the digital tracking of Screenrights streaming service EnhanceTV in 2017. However, the collection task remains quite separate from the difficult task of identifying, assessing and resolving the competing claims that collectively form the disbursement work for these funds. In short, successful collection of funds does not equate to successful disbursement of funds. As educators are not in receipt of these funds, these tensions between Screenrights and their screen sector members go largely unacknowledged by educators. Understandably, the Screenrights members standing to benefit directly from the disbursement of these funds remain engaged with this issue.

Some educators may understandably bridle at the prospect of the screen sector seeking to profit from education. However, these objections overlook the longstanding educative and economic reciprocal relationship between the two sectors, particularly around the valuing of documentary and attendant remuneration of that use. In short, much like educators, documentary makers are not 'in it' for the money. The funds returned to the documentary sector from educational valuing of their content ensures that more future documentaries can be created and deployed within education. In his 2019 paper 'The changing landscape of Australian documentary', Tom Zubrycki (2019: 67) quotes US documentary film producer Diane Weyermann in this regard: 'The documentary world is not driven by money or the business but driven by a person's commitment to a story and how doggedly they pursue it, financing or not.' Far removed from 'Hollywood accounting' or the box office returns commanded by feature films, the documentary sector, much like education, is not a calling for those who desire riches. Driven, passionate professionals seeking to enact change underpin both sectors. This is a valuable reflection as financial tensions around educational use and remuneration of documentary continue to play out in the Australian context. 


\section{Notes on the contributor}

Ruari Elkington is a lecturer in creative industries at Queensland University of Technology, Australia. His research is grounded in the industry context of screen distribution with a focus on documentary filmmaking and how documentary storytelling connects youth and education audiences. Other research areas of focus include reciprocal learnings between Australian YouTube content creators and formal education. He has published in the field of documentary screen distribution, screen studies and education. His scholarship remains driven by questions of how screen content connects with discrete audiences in markets increasingly under pressure from creative and commercial tensions.

\section{Filmography}

Blame (AU 2010, Michael Henry)

The Inauguration of the Commonwealth (AU 1901, Joseph Perry)

The Triangle Wars (AU 2011, Rosie Jones)

Wide Open Road (AU 2011, Paul Clarke)

\section{References}

AFC (Australian Film Commission) (2004) 'Documentary production and funding in Australia: A discussion paper'. Online. https://trove.nla.gov.au/work/14262748 (accessed 15 February 2017).

ALRC (Australian Law Reform Commission) (2013) Copyright and the Digital Economy. Discussion Paper. Online. https://www.alrc.gov.au/publication/copyright-and-the-digital-economy-dp-79/ (accessed 12 June 2016).

ALRC (Australian Law Reform Commission) (2014) Copyright and the Digital Economy. Online. www.alrc.gov.au/publications/copyright-report-122 (accessed 23 April 2016).

ATOM (Australian Teachers of Media Queensland) (2014) 'Home'. Online. www.atomqld.org.au/ (accessed 30 September 2017).

Aufderheide, P. (2007) Documentary Film: A very short introduction. Oxford: Oxford University Press. Bradley, G. (2014) Interview with author. 12 April, Brisbane.

Burns, A. and Eltham, B. (2010) Boom and bust in Australian screen policy: 10BA, the Film Finance Corporation and Hollywood's 'race to the bottom'. Media International Australia, 136 (1), 103-18. Online. https://doi.org/10.1177/1329878X1013600113.

CAG (Copyright Advisory Group for Schools of the Standing Council on School Education and Early Childhood) (2013) 'Submission to the Australian Law Reform Commission - Discussion paper 79 (DP 79): Copyright and the digital economy'. Online. www.alrc.gov.au/wp-content/ uploads/2019/08/707_org_cag_schools_submission_-_dp79_-_final_version.pdf (accessed 3 March 2018).

eTV (2014) eDMC Pilot: Extending New Zealand Documentaries with Enhanced Digital Media Content. Document supplied to author privately.

FitzSimons, T., Laughren, P. and Williamson, D. (2011) Australian Documentary: History, practices and genres. Cambridge: Cambridge University Press.

Fraser, N. (2012) Why Documentaries Matter. Oxford: Reuters Institute for the Study of Journalism, Department of Politics and International Relations, University of Oxford.

Gorski, P. (2003) 'Ten powerful films for teacher educators and crucial reflections before using them'. Multicultural Perspectives, 5 (2), 28-33. Online. https://doi.org/10.1207/S15327892MCP0502_6.

Hess, D. (2007) 'From Banished to Brother Outsider, Miss Navajo to An Inconvenient Truth: Documentary films as perspective-laden narratives'. Social Education, 71 (4), 194-9.

Janson, M. (2019) 'Moulding the democratic citizen of the future: On the discourses and practices of film education in Sweden'. Film Education Journal, 2 (2), 85-100. Online. https://doi.org/10.18546/FEJ.02.2.01.

Lean, M. (2000) Interview with author. 4 August, Brisbane.

Menchik, D.A. (2004) 'Placing cybereducation in the UK classroom'. British Journal of Sociology of Education, 25 (2), 193-213. Online. https://doi.org/10.1080/0142569042000205118. 
NSFA (National Film and Sound Archive) (2013) 'National Film and Sound Archive of Australia: Annual Report 2012-13'. Online. www.nfsa.gov.au/collection/curated/12-13-annual-report (accessed 22 November 2016).

Screen Australia (2014) 'Documentary funding: Stories that matter'. Online. www.screenaustralia. gov.au/getmedia/905c3ce2-95a6-4d98-9e71-0eb03e947380/Guidelines-Submission_ ABC_20140718.pd (accessed 11 July 2016).

Screenrights (2009) Screen Australia Stage 2 Review - Marketing Support \& Promotion. Online. www.screenaustralia.gov.au/getmedia/d13c87f3-f431-444b-b591-9de380bef163/EnTVScr-Stage2-response.doc (accessed 14 December 2019).

Screenrights (2012) 'Submission to NZ ON Air documentary funding policy discussion paper'. Online. www.screenrights.org/wp-content/uploads/2017/10/nzonairsubmissionfinal.pdf (accessed 2 November 2012).

Screenrights (2020) 'What we do'. Online. www.screenrights.org/about-us/what-we-do/ (accessed 27 October 2020).

Shelton, S.M. (2004) Communicating Ideas with Film, Video, and Multimedia. Carbondale, IL: SIU Press.

Stoddard, J.D. (2009) 'The ideological implications of using "educational" film to teach controversial events'. Curriculum Inquiry, 39 (3), 407-33.

Tapp, P. (2014) Interview with author. 3 February, Brisbane.

Tiley, D. (2013) 'Copyright: Proposed changes to fair use are very unfair'. Online. www.artshub. com.au/news-article/news/film/screenhub/copyright-proposed-changes-to-fair-use-are-veryunfair-240929 (accessed 28 June 2013).

UA (Universities Australia) (2012) 'Response to the ALRC issues paper: Copyright and the digital economy November 2012'. Online. www.universitiesaustralia.edu.au/wp-content/ uploads/2019/05/ALRC-Submission-301112.pdf (accessed 2 April 2018).

Zubrycki, T. (2019) 'The changing landscape of Australian documentary', Platform Papers 58 Currency House, Sydney, February. 